Rathnasiri R.A. \& Mohottige S.

Wayamba Journal of Management 12 (2)

\title{
Impact of Turnover Intention on Team Effectiveness of Floor Level Employees of the Five Star Hotels in the Western Province of Sri Lanka
}

\author{
R.A. Rathnasiri ${ }^{1} \&$ S. Mohottige $^{2}$ \\ ${ }^{1}$ Department of Banking and Finance \\ Faculty of Business Studies \& Finance \\ Wayamba University of Sri Lanka Kuliyapitiya \\ SRI LANKA \\ ${ }^{2}$ Department of Business Management \\ Faculty of Business Studies \& Finance \\ Wayamba University of Sri Lanka Kuliyapitiya \\ SRI LANKA \\ ranasingher76@gmail.com ${ }^{1}$, smohottige1@ gmail.com²
}

\begin{abstract}
A team is a group in which members work together intensively to achieve common group goal. Teamwork is very important in the hotel industry as effective teams generate positive synergy. Team effectiveness is the capacity of a team to accomplish the goals or objectives. Teams are created in an organization and processes are improved to increase competitive advantage. To create and implement team effectively, management system must be designed to fit the team environment to enhance the productivity. The purpose of this study is to assess the impact of turnover intention on team effectiveness of floor level employees of the five-star-hotels in the western province of Sri Lanka. Research model was developed as a result of the comprehensive literature survey based on the deductive research approach. Proportionate simple random sampling technique was used to select 217 respondents from 3221 total respondents of the selected five-star hotels in the western province of Sri Lanka. Primary data was employed to analyze the data using five point- Likert scale. A structured questionnaire which contained 35 questions was employed to collect primary data from the respondents. Correlation and regression analyses were the main analytical tools employed in this study. The results of the analysis showed that turnover intention has a significant impact on the team effectiveness. It means that Team effectiveness has been substantially influenced by the Predictor variables: Fringe Benefits, Career Development Opportunities, Work environment, Organizational Characteristics and Nature of work. Multiple regression analysis envisaged that $49.9 \%$ variation in the team effectiveness has been explained by the estimated multiple regression model. Finally, the finding of the study is useful to the policy makers to design and implement
\end{abstract}


appropriate policies to retain hotel staff and develop hotel industry in Sri Lanka.

Keywords-: Fringe Benefits, Career Development, Organizational Characteristics, Working Environment, Team Effectiveness, Turn Over Intention.

\section{INTRODUCTION}

Present study was designed to investigate the impact of turnover intention on team effectiveness of floor level employees of the Five Star Hotels in the Western Province of Sri Lanka. The annual turnover rate of hotel sector was always between $10 \%-18 \%$ and it was above the industry average of 1.4 per cent since 2010 (CBSL, 2017). It was found to have a heavy volume of teamwork problems in the hotel sector (see Table 1 for more information).

An organization is a teamwork, where many individuals work together to achieve a common goal. Teamwork is essential in an organization so that a teamwork friendly management system should be designed (Jones and George, 1998). Teamwork is very important in the hotel industry. Effective teams generate positive synergy. Due to low compensation packages and heavy, continuous workloads of employees in the hotel industry, floor level employees are always searching for new job opportunities in another hotel. Work teams are therefore, continuously faced with contextual related problems, compositional related as well as process related problems. There are many other factors that influence employee turnover, organizational size, coworkers, supervisors, pay, promotional aspects, job itself may influence employee turnover (Robbins et al.,2016).

The tourism sector has been experiencing an impressive growth both in terms of tourist arrivals and in foreign exchange revenues after the restoration of peace and normalcy in the country in 2009 (See Table 1). Achieving another remarkable milestone in the country's booming tourism industry, tourist arrivals reached half million in 2014, an increase of $20 \%$ over 2013 and foreign exchange earnings exceeded US\$ 2.4 billion, an increase of $41 \%$ over 2013 (CBSL, 2017).

\subsection{Problem of the Study}

Service sector contributed 63 percent to the Gross Domestic Product (GDP) in 2010 and onwards in Sri Lanka. (CBSL 2015). By the way, the tourism industry in Sri Lanka is growing continuously and it contributes to GDP significantly. Many researchers have discovered that the hotel industry is facing the problems of overcoming personnel shortages (Mohamad Nurzeti, 2010). It reflects the high employee turnover rates and shortages of skilled-human resources in the industry. The annual turnover rate was always 
above the one digit since the year 2010 and found to be a heavy volume of teamwork problems. As per the Annual Reports of the Central Bank of Sri Lanka (2013 2017), annual turnover rates in the hotel sector increased from $13 \%$ to $18 \%$.

The annual turnover rate was always above the one digit since the year 2010 and found to be a heavy volume of teamwork problems. Table 1 (see appendix) depicts the annual turnover rates during the last five years.

Present study attempts to investigate to what extent Fringe Benefits, Career Development Opportunities, Work Environment, Organizational Characteristics and Nature of Work which could explained under the Turnover Intention and the possible impact on team effectiveness of floor level employees in the five-star hotels of Western Province of Sri Lanka. Accordingly, the following research objectives were formulated.

a. To investigate the impact of Turnover Intention on Team Effectiveness of floor level employees of the Five-Star-Hotels in the Western Province of Sri Lanka.

b. To identify the most influential factor which affects the Team Effectiveness in the five- star hotels of Western Province of Sri Lanka.

\section{LITERATURE REVIEW}

This section reviews the literature relating to the team effectiveness, turnover Intention and measuring concepts: Fringe Benefits, Career Development Opportunities, Organizational Characteristics, Work Environment, and the Nature of the Work its.

\subsection{Team effectiveness}

When organizations use extrinsic rewards as payoffs for superior performance, employees feel they are doing a good job, because of their own intrinsic desire to excel than because that is what the organization wants. Organizational effectiveness is influenced to a great degree by the external environmental characteristics. It is dependent on how the external environment is predictable, complex and antagonistic to the organization and its activities. The major characteristics are predictability, complexity and hostility.

Team Effectiveness referred to as team performance, is a team's capacity to achieve its goals and objectives. This capacity to achieve goals and objectives leads to improved outcomes for the team members, as well as outcomes produced or influenced by the team (Marks, Mathieu, and Zaccaro, 2001;Kozlowski and Ilgen, 2006; Salas, Goodwin, and Burke, 2009).A team is a collection of individuals who are interdependent in their tasks, 
share responsibility for outcomes, and view themselves as a unit embedded in an institutional or organizational system which operates within the established boundaries of that system(Halvorsen, Kristin (2013). Effective teams are made up of members who have the skills necessary to accomplish their goals. Everyone brings their own viewpoints and knowledge to the group. Members engage in open communication, using active listening and responding. In the most effective teams, co-workers trust and support one another. The importance of work teams appears to be gaining in strength as jobs get bigger, organizational structures get more complex, and more and more companies become multinational in scope (Naquin and Tynan, 2003).

Successful teams are deeply committed to their goals, approach, and purpose. Members in these teams also are very committed to each other. They understand that the "Wisdom of a team comes with a focus on collective work products, personal growth, and performance results" (Ketzenbach and Smith,1993). They assert that successful teams always are a result of pursuing demanding performance goals at the team level.

\subsection{Turnover intention}

Employees leaving their current positions and taking new positions within the same organization refers to internal turnover. There are both positive and negative effects of internal turnover. The positive effects are increasing employees' morale. The negative effects are dangerous. Mainly rational disruption internal turnover may be controlled by human resources mechanisms, such as internal policies and procedures. Internal turnover can be a transfer from one location to the other. Typically, such actions are punishment based. Large amount of internal transfers leaving a particular department or division. In that area unless that position is designated steppingstone position (Bruno Stafflbach, 2010).

Since turnover is often associated with job dissatisfaction, most researchers argue that turnovers are voluntary and subject to control by managers (Morrell et al., 2001). Voluntary turnover is possible when employees choose to leave for whatever the reasons. Involuntary turnover is caused by layoffs and similar action where the decision for an employee to leave is made by the organization, but not by the employees. Generally voluntary turnover is measured in percentage to the total labor force. Involuntary turnover caused by layoffs (Boxall et al., 2003).

Having understood, turnover intention is a withdrawal behavior which is in general a set of actions that employees take to separate themselves from the organization. There are many forms of withdrawal ranging from showing 
up later or failing to attend meetings to absenteeism and turnover (Robbins, 2015). Employee withdrawal can have a very negative effect on an organization.

\subsection{Turnover intention and measurement indicators}

\subsubsection{Fringe benefits}

The success and the survival of any organization are determined by the way the workers are compensated. The reward system and motivating incentives will determine the level of employees' commitment and their attitude to work. Fringe benefits are forms of indirect compensation given to an employee or group of employees as a part of organizational membership. Bratton and Gold (2009) defined them as that part of the total reward package provided to employees in addition to base or performance pay. Fringe benefits focus on maintaining (or improving) the quality of life for employees and providing a level of protection and financial security for workers and for their family members. Like base pay plans, the major objective for most organizational fringe compensation programs is to attract, retain and motivate qualified, competent employees (Bernardin, 2017). Mathis and Jackson (2013) continue to state that an employer that provides a more attractive benefits package often enjoys an advantage over other employers in hiring and retaining qualified employees when the competing firms offer similar base pay. In fact, such benefits may create "golden handcuffs," making employees more reluctant to move to other 2 employers. Some common examples are; retirement or pension plans, medical and dental insurance, education reimbursement, time off, paid vacation and use of company cars.

\subsubsection{Career development opportunities}

The theory of Mondy (2010) that career development is a formal approach used by companies to ensure that people with the right qualifications and experience are available when needed. Also according to Mondy, an important role in human resource management is a career development system that aims to attract, retain, and at the same time motivate employees to have a better work spirit. With the motivation of a good career development in a company, it will be directly proportional to the quality and quantity that is good for human resources in a company. Handoko (Hafi, 2016) suggests that career development is an effort made by an employee to achieve a career plan. Companies that cannot provide career development to their employees will have a greater risk of losing their employees if compared with companies that can provide a more open career path to their employees. According to Handoko (Hafiz, 2016) there are several indicators 
of career development, namely (1) work performance, (2) exposure, (3) loyalty, (4) mentors and sponsors, (5) opportunities to grow, (6) Management support. The theory underlying the relationship between career development and turnover intention is the theory expressed by Sari Hafiz, 2016) that one of the factors that need to be a concern of the company to reduce employee turnover is how companies provide career development opportunities for these employees and there is an effort to manage human resources well on an ongoing basis organizational career growth shows potential for managing turnover, its biggest impact is on those who desire a career (Weng and McElroy, 2012).

\subsubsection{Work environment}

Elements of environment assume an imperative part towards the employees' performance. The variables of the environment give an enormous effect to the employees' results either positively or negatively (Chandrasekar, 2011). In the course of the most recent decades, the components of the work environment of the office workers had changed because of the adjustments in a few factors, for example, the social environment, information technology and the adaptable methods for sorting out work forms (Zafir \& Fazilah, 2011).

Employees will work harder and increase performance when they have a great work environment. According to Chei et al., (2014), the capacity for employees to impart information to each other relies upon how the environment is utilized. This encourages organizations to expand value regarding profit, level of aggressiveness and others. Safety and health working conditions are one of the highlights that organizations need to consider. A threatening workplace is probably going to cause physical disharmony. Poor and hazardous workplace will convey genuine risk to employees. Organizations additionally see that office outline and format will bring in a successful management process and this will expand employee performance.

Other than that, lighting is also part of the working environment. Mills, Tomkins, and Schlangen (2007) stated that brightness and wavelength of light have an impact on task performance and human system like mood and alertness. According to Hameed and Amjad (2009), office layout and design, which are defined by good design and layout of the workplace, can make employees perform better. Office design and work performance are interrelated.

\subsubsection{Organizational characteristics}

Organizational characteristics refer to the general conditions that exist within an organization. Various organizational characteristics influence 
organizational effectiveness. The major characteristics are structure, technology, innovation and development corporate governance. An organizational structure defines how job tasks are formally divided, grouped and coordinated. For organizational effectiveness, six elements need to be addressed while designing organizational structure. These are: work specialization, departmentalization, chain of command, span of control, centralization and decentralization, and formalization. Complex organizational structures can often lead to ineffective execution of the business strategy. No one element by itself can drive sustainable business results-all elements must be working together toward the same goal in order to get strategy execution right. These elements work together, mutually reinforcing each other, and must be focused and aligned to effectively achieve execution.

\subsubsection{Nature of work}

Work climate, which is mostly known as the nature of the job, is strongly related to the individual's level of job satisfaction, job involvement, employee commitments and employee motivation. However, a positive overall workplace climate is being linked with higher customer satisfaction and employee performance.

Nature of the job partly depends on the chain of command principle, supervisor or manager or higher rankers for whom subordinates (may be managers or even non managers) are responsible. Another important determinant is unity of command principle. Existence of dual command (two supervisors - one subordinate) causes severe breakdowns in authority and discipline. Employees should receive orders from only one supervisor. It is believed that recognition and observance of this principle would eliminate the causes of interdepartmental and interpersonal conflicts that are aroused leads to jurisdictional issues. Further, clarity of task influences employee performance. Some supervisors feel that they can do the job faster without subordinates (Donnelly, 2001)

In the short run it may be possible and correct, but in the long run, it is a myopic leads number of problems in the office, however assigning people at work by delegating authority enable the subordinates to develop competence and free the supervisor to devote his or her valuable time to another important task, may be fruitful and there are number of advantages, yet the most important task which is urgent, manager must do, while planning other jobs to assigned with others with properly delegated(Donnelly, 2001).

Having too much to do with too little time to do it is a common perception in the workplace. This problem is often referred to as work or role overload. Proper 
workload management is an essential part in nowadays working environment as the majority of firms expect their employees to increase their productivity in order to cope with more work.

Work pressure created by negative core workers; those who are less competitive, less skill attempts are made to disturb other workers who have more skills and more competitive advantages.

Work pressure created by Negative supervisory behavior; this is due to inferiority because they have come from dirty blood associated with less people.

\section{METHODS}

\subsection{Conceptual framework}

The following conceptual model developed based on the literature review (See figure 1). Accordingly fringe benefits, career development opportunities, working conditions, organizational structure and nature of the workload identified as the indicators of turnover intention which will have an impact on team effectiveness of the organization.

\subsection{Hypothesis}

The following Hypotheses were formulated on the basis of the conceptual model shown above.

H1: There is a significant positive impact of Fringe Benefits on Team Effectiveness of five-star hotels in the Western Province of Sri Lanka.

H2: There is a significant positive impact of Career Development Opportunities on Team Effectiveness of five-star hotels in the Western Province of Sri Lanka.

H3: There is a significant positive impact of Work Environment on Team Effectiveness of five-star hotels in the Western Province of Sri Lanka.

H4: There is a significant positive impact of Organizational Characteristics on Team Effectiveness of five-star hotels in the Western Province of Sri Lanka.

H5: There is a significant positive impact of Nature of Work itself on Team Effectiveness of five-star hotels in the Western Province of Sri Lanka.

H6: Variance in Team Effectiveness of five-star hotels in the Western Province of Sri Lanka is significantly explained by the Turnover Intention related variables.

\subsection{Data and technical root of the study}

This study was conducted by distributing the 217 questionnaires to Five Star hotel employees in Western Province of Sri Lanka. There are 31 five-star hotels operated in the island. And there are 16 five-star hotels operated in the Western Province. The five hotels selected for the sample represent $31 \%$ five star hotels of the Western Province and $16 \%$ of total five star hotels in 
Sri Lanka. Sample size was determined in accordance with the Morgan Table (Uma Sekeran, 2013). The questionnaire was composed of two sections, the first section solicited demographic information about respondents, while the second part was related to employee performance. The items were measured using the 5point Likert scale, where 5 refers to "strongly agree" and 1 refers to "strongly disagree" for each and every statement in the questionnaire. The scale was adopted from Sekaran, (2013).

It includes descriptive data analysis and the inferential data analysis for which Pearson's correlation coefficient analysis was performed to assess the relationship between each independent variable and the dependent variable and Linear regression analysis was performed in order to find the impact of turnover intention on team effectiveness.

\section{RESULTS}

\subsection{Reliability analysis}

Table 02 shows Cronbach's Alpha for the independent and dependent variables. The closer the Cronbach's Alpha is to 1 , the higher the internal consistency reliability. As pointed out by Sekaran (2013), the reliability that is less than 0.60 is considered as poor and if it is in the range of 0.70 , it is considered as acceptable. As per Table 02, above reliability of the items of the questionnaire were found strong as Cronbach's Alpha values were always more than point seven.

\subsection{Descriptive data analysis}

Table 3 presents the descriptive statistics of the sample selected for the study. From Table 03, four (04) variables indicate mean value more than 3.18 out of five-point scale which indicates a good result for Likert scale (Sekaran, 2013). Mean value shows the average that is used to derive the central tendency of the data in question. In this study, the mean value for four variables is close to 4.0 , which indicates that most of the respondents have provided favorable responses for four questions asked. Mean value for one variable falls below 3.0 and indicates that respondents have provided an unfavorable response for the questions related to "Career Development Opportunities".

\subsection{Correlation analysis}

To examine the relationship among Fringe Benefits, Career Development Opportunities, Work Environment, Organizational Characteristics, Nature of Work and Team Effectiveness. Pearson correlation coefficient analysis methods were used to compute the correlation and the strength of different variables. Table 04 displays the correlations among all of these variables in the model. All the variables or corresponding values are found to be greater than 0.712 . 
Hence there are significant positive relationships between independent variables and Team Effectiveness of five-star hotels in the Western Province of Sri Lanka.

\subsection{Regression analysis}

In accordance with the Table 05, ANOVA for multiple regression, $\mathrm{p}$ value $=0.000$, which is less than 0.01 . The F statistic is 195.30 is significant. The model of the regression is capable of explaining the regression variation. Predictor variables: Fringe Benefits, Career Development Opportunities, Work Environment, Organizational Characteristics and Nature of Work have been able to explain the variance in the dependent Variable (Team Effectiveness).

As per Table 06 in appendix, parameter estimates indicate that all the predictor variables have a significant impact on the dependent variable. It means that Team Effectiveness has been substantially influenced by the Predictor variables: Fringe Benefits, Career Development Opportunities, Work Environment, Organizational Characteristics and Nature of Work.

Fringe Benefits is the highest contributor Beta Value $=0.353$. Nature of Work becomes the second highest contributor Beta Value $=0.189$. Work Environment is the third contributor Beta Value $=0.168$.
Career

Development Opportunities is the fourth contributor Beta Value $=0.145$. Organizational Characteristics is the fifth contributor Beta Value $=$ 0.093 .

\section{FINDINGS AND DISCUSSION}

As per inferential data analysis, Correlation coefficient between Fringe Benefits and Team Effectiveness is high, $r=0.712$. $R$ Square is 0.507 , which indicates that Team Effectiveness is positively influenced by Fringe Benefits. F statistic $(F=45.992)$ which is statistically significant, Beta coefficient value $=0.238$. Therefore, H1 is accepted. Hence there is a significant positive relationship between Fringe Benefits and Team Effectiveness of five-star hotels in the Western Province of Sri Lanka and concluded that Fringe Benefits positively influence Team Effectiveness.

Correlation coefficient between Career Development Opportunities and Team Effectiveness is high, $\mathrm{r}=0.715, \mathrm{R}$ Square is 0.511 , which indicates that Team Effectiveness is positively influenced by Career Development Opportunities. F statistic $(\mathrm{F}=70.412)$ which is statistically significant, Beta coefficient value $=0.191$. Therefore, H2 is accepted. Hence there is a significant positive relationship between Career Development Opportunities and Team Effectiveness of five-star 
hotels in the Western Province of Sri Lanka and concluded that Career Development Opportunities positively influence Team Effectiveness.

Correlation coefficient between Work Environment and Team Effectiveness is high, $\mathrm{r}=0.718$. $\mathrm{R}$ Square is 0.515 , which indicates that Team Effectiveness is positively influenced by the Work Environment. $\mathrm{F}$ statistic $(\mathrm{F}=$ 51.361) which is statistically significant, Beta coefficient value $=0.12$. Therefore, H3 is accepted. Hence there is a significant positive relationship between Work Environment and Team Effectiveness of five-star hotels in the Western Province of Sri Lanka and concluded that Work Environment positively influences Team Effectiveness.

Correlation coefficient between Organizational Characteristics and Team Effectiveness is high, $r$ $=0.791$. R Square is 0.625, which indicates that Team Effectiveness is positively influenced by Organizational Characteristics. $\mathrm{F}$ statistic $(\mathrm{F}=46.607)$ which is statistically significant, Beta coefficient value $=0.113$. Therefore, H4 is accepted. Hence there is a significant positive relationship between Organizational Characteristics and Team Effectiveness of fivestar hotels in the Western Province of Sri Lanka and concluded that Organizational Characteristics positively influence Team Effectiveness.
Correlation coefficient between Nature of Work and Team Effectiveness is high, $\mathrm{r}=0.724$. $\mathrm{R}$ Square is 0.524 , which indicates that Team Effectiveness is positively influenced by Nature of Work itself. F statistic ( $\mathrm{F}=51.361)$ which is statistically significant, Beta coefficient value $=0.187$. Therefore, H5 is accepted. Hence there is a significant positive relationship between Nature of Work and Team Effectiveness of five-star hotels in the Western Province of Sri Lanka and concluded that Nature of Work positively influences Team Effectiveness.

Model summary of the Multiple Regression, $\mathrm{R}$ squared value is 0.499, therefore it can be predicted that $49.9 \%$ variation in Team Effectiveness has been explained by the predictor variables. Parameter Estimates indicate that all the predictor variables have a significant impact on the dependent variable. It means that Team Effectiveness has been substantially influenced by the Predictor variables: Fringe Benefits, Career Development Opportunities, Work environment, Organizational Characteristics and Nature of Work. These findings are in line with the previous literature (Bernardin, 2017; Weng and McElroy, 2012; Hameed and Amjad 2009; Donnelly, 2001). Fringe Benefits is the highest contributor Beta Value $=0.353$, Nature of Work becomes the 
second highest contributor Beta Value $=0.189$, Work Environment is the third contributor Beta Value $=0.168$, Career Development Opportunities is the fourth contributor Beta Value $=0.145$, Organizational Characteristics is the fifth contributor Beta Value = 0.093 .

Teamwork is a huge factor in hospitality industries around the world. Most hospitality industries including tourism and hospitality survive by teamwork. Teamwork in the tourism industry has great importance for more than one reason. Teamwork brings a sense of security, trust, and loyalty to employees as well as the employers. Without teamwork, morale can be lowered. If morale is lowered, then productivity could be lowered as well. Hospitality industries are aware of this fact, so they implement programs and activities to keep morale and productivity at its highest attainable level. Teamwork in the company has great importance for more than one reason. Hospitality industries, who have embraced the concept, have reported increased performance in work production, problem solving and have stimulated new growth. This group project approach has improved employee morale and increased input when managed correctly. The benefits of teamwork can make a positive effect in the company that incorporates this type of teamwork approach. Resources must be available within the company or outsourced by businesses that will come in and train company employees to make the most effective effort. A highperformance workplace focuses on increasing people's influence on the business as well as the impact of processes, methods, the physical environment, and the technology and tools that enhance their work.

Teamwork is the ability to work together toward a common vision. Moreover, it explains the ability to direct individual accomplishments toward organizational objectives. It is the fuel that allows common people to attain uncommon results. A team is a small number of individuals associated in some joint action, with a strong, deep seated, common sense of purpose. Team members are mutually committed, mutually supportive, and collectively responsible for the achievement of team goals and objectives. Real teams create synergy; they perform at levels above that of groups. Team members work closely and freely with each other to achieve their common performance goals. Real teams perform tasks that cannot be achieved by individuals alone Effective teams consist of members who have the skills necessary to accomplish their own and group goals. It is crucial for every team member in an effective team to bring their own knowledge and viewpoints to the entire group. They should know 
everything about open communication, active listening and responding.

All members of effective teams are accountable for achieving goals and are motivated to do well. They trust and support one another. Why do we need any model for team effectiveness? It can help to figure out which attitude, tools, and strategies to adapt for your own team. Perhaps, it will assist to shed light on what is working and what is not in your own team.

\section{CONCLUSION RECOMMENDATIONS}

AND

\subsection{Conclusion}

Respondents are not satisfied with the Salary. But satisfied with Service Charges, Medical Benefits, Welfare Facilities, Food and Accommodations. Respondents are less satisfied with Career Advancement Opportunities, Job Security, Career Development Opportunities, Cross Exposure and Promotions. Respondents are found to be less satisfied with senior management and with Supervisors. However, they are found to be satisfied with peers, with other employees and the level of Interpersonal relationship maintained.

Respondents are found to be satisfied with opportunities and skills can be used, recognition given by Management, Corporate
Culture, relationship with coworkers, relationship with supervisors they have, agreed that they indifferent with task freedom, satisfied with role freedom, satisfied with the behavior of supervisors, with authority provided, but not satisfied with job freedom and work life balance.

Respondents clearly indicate that they are able to provide timely delivery of services, minimum number of guests' complaints, positive Social Media comments, minimum number of conflicts created by team members and minimum level of loafing by the team members.

Fringe Benefits, Career Development Opportunities, Work Environment, Organizational Characteristics and Nature of Work have been able to explain the variance in the dependent Variable (Team Effectiveness). Model summary of the Multiple Regression, $\mathrm{R}$ squared value is 0.499 therefore it can be predicted that $49.9 \%$ variation in Team Effectiveness has been explained by the predictor variables.

Parameter estimates indicate that all the predictor variables have a significant impact on the dependent variable. It means that Team Effectiveness has been substantially influenced by the Predictor variables: Fringe Benefits, Career Development Opportunities, Work Environment, Organizational 
Characteristics and Nature of work.

Fringe Benefits is the highest contributor Beta Value $=0.353$, Nature of Work becomes the second highest contributor Beta Value $=0.189, \quad$ Work Environment is the third contributor Beta Value $=0.168$, Career Development Opportunities is the fourth contributor Beta Value $=0.145$, Organization Characteristics is the fifth contributor Beta Value = 0.093 .

\subsection{Recommendations}

Study recommends that Salary and allowances of floor level employees to be revised taking into consideration industry standards, while Service Charges, Medical Benefits, Welfare Facilities and Food and Accommodations to be revised incompliance with the present living expenses in the country.

Respondents are dissatisfied with Career Advancement Opportunities available to them; also they are dissatisfied with Job Security, Career Development Opportunities, Cross Exposure and Promotions. Therefore, the study recommends that hotel management should take necessary arrangements to enhance the level of Career Development Opportunities in the future.

Respondents are found to be less satisfied with senior management and with supervisors. However, they are found to be satisfied with peers, with other employees and the level of Interpersonal relationship maintained. Therefore, the study recommends that hotel management should take necessary arrangements to reinforce the evidence of organizational justice to the employees.

However, respondents are found to be satisfied with opportunities and skills that they can use in the hotel, recognition given by Management, Corporate Culture, relationship with co-workers, and relationship with supervisors. Therefore, the study recommends that hotel management should take necessary arrangements to maintain the existing level of interpersonal relationships between and among employees.

Respondents have agreed that they are satisfied with task freedom, satisfied with role freedom, satisfied with the behavior of supervisors, with authority provided, with job freedom and work life balance. Therefore the study recommends that hotel management should take necessary arrangements to maintain the existing level of employee job autonomy in the respective hotel.

Respondents clearly indicate that they are able to provide timely delivery of services, minimum number of guests' complaints, positive Social Media comments, minimum number of conflicts created by team members and minimum level of loafing by the team members. Therefore, study recommends that hotel 
Rathnasiri R.A. \& Mohottige S.

Wayamba Journal of Management 12 (2)

management should be able to

manage the existing policy

framework favorable to relevant

parties in the respective hotel. 


\section{APPENDIX}

Table 01: Annual Turnover Rates in Hotel Sector 2013 - 2017

\begin{tabular}{|l|c|c|c|c|c|}
\hline \multicolumn{1}{|c|}{ Year } & $\mathbf{2 0 1 3}$ & $\mathbf{2 0 1 4}$ & $\mathbf{2 0 1 5}$ & $\mathbf{2 0 1 6}$ & $\mathbf{2 0 1 7}$ \\
\hline Number of Employees & 43715 & 48611 & 54050 & 60022 & 61255 \\
\hline Number of employees left & 4311 & 5428 & 5881 & 5785 & 6041 \\
\hline Number of employees recruited & 6323 & 7315 & 8223 & 10115 & 10348 \\
\hline Annual Turnover Rate & $10 \%$ & $12 \%$ & $13 \%$ & $11 \%$ & $18 \%$ \\
\hline
\end{tabular}

Source- Annual Reports, 2013 - 2017, Central Bank of Sri Lanka

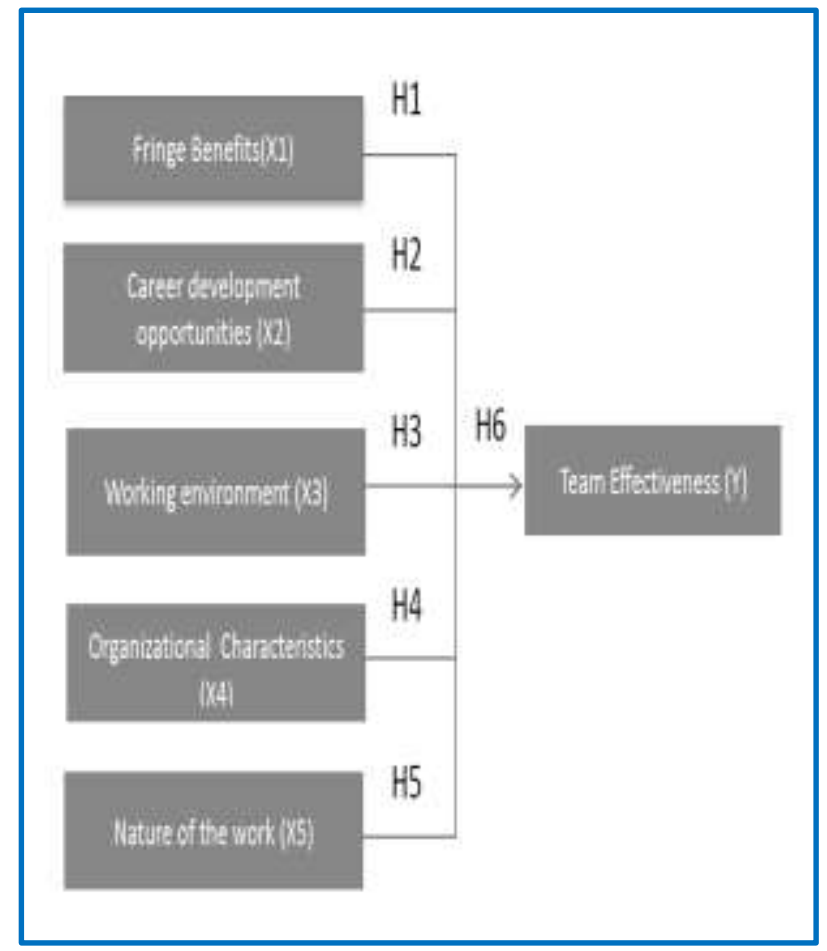

Figure 1. Conceptual Model 
Rathnasiri R.A. \& Mohottige S.

Wayamba Journal of Management 12 (2)

Table 02: Reliability Analysis

\begin{tabular}{|c|c|l|c|}
\hline VARIABLE & Code & \multicolumn{1}{|c|}{ DIMENSIONS } & CRONBACH'S \\
& & & ALPHA VALUE \\
\hline Independent & $\mathrm{X} 1$ & Fringe Benefits & 0.725 \\
\hline Independent & $\mathrm{X} 2$ & Career Development & 0.716 \\
\hline Independent & $\mathrm{X} 3$ & Working Environment & 0.719 \\
\hline Independent & $\mathrm{X} 4$ & $\begin{array}{l}\text { Organizational } \\
\text { Characteristics }\end{array}$ & 0.727 \\
\hline Independent & $\mathrm{X} 5$ & Nature of the work & 0.719 \\
\hline Dependent & $\mathrm{Y}$ & Team Effectiveness & 0.709 \\
\hline
\end{tabular}

Source: Based on Survey Data

Table 03: Descriptive Statistics

\begin{tabular}{|l|c|c|c|c|c|}
\hline \multicolumn{1}{|c|}{ VARIABLE } & N & $\begin{array}{c}\text { Minimu } \\
\mathbf{m}\end{array}$ & $\begin{array}{c}\text { Maximu } \\
\mathbf{m}\end{array}$ & Mean & $\begin{array}{c}\text { Std. } \\
\text { Deviation }\end{array}$ \\
\hline Fringe Benefits & 217 & 1 & 4 & 3.184 & 0.7253 \\
\hline Working Environment & 217 & 1 & 4 & 3.742 & 0.7986 \\
\hline $\begin{array}{l}\text { Career Development } \\
\text { Opportunities }\end{array}$ & 217 & 1 & 4 & 2.68 & 0.8510 \\
\hline Organizational Characteristics & 217 & 1 & 4 & 4.28 & 0.6856 \\
\hline Nature of Work & 217 & 1 & 4 & 3.74 & 0.7077 \\
\hline Team Effectiveness & 217 & 1 & 1 & 4.46 & 0.7611 \\
\hline
\end{tabular}

Source: Authors Calculation Based on Survey Data 
Rathnasiri R.A. \& Mohottige S.

Wayamba Journal of Management 12 (2)

Table 04: Correlation Matrix

\begin{tabular}{|l|c|c|c|c|c|c|}
\hline \multicolumn{1}{|c|}{ VARIABLE } & x1 & x2 & x3 & x4 & x5 & Y \\
\hline Fringe Benefits (x1) & 1 & & & & & .712 \\
\hline $\begin{array}{l}\text { Career Development } \\
\text { Opportunities (x2) }\end{array}$ & & 1 & & & & .715 \\
\hline Working Environment (x3) & & & 1 & & & .718 \\
\hline $\begin{array}{l}\text { Organizational Characteristics } \\
\text { (x4) }\end{array}$ & & & & 1 & & .791 \\
\hline Nature of Work (x5) & & & & & 1 & .724 \\
\hline Team Effectiveness (y) & .712 & .715 & .718 & .791 & .724 & 1 \\
\hline
\end{tabular}

Source: Authors Calculation Based on Survey Data

Table 05: ANOVA Multiple Regression

\begin{tabular}{|l|l|l|l|l|l|l|}
\hline \multicolumn{2}{|c|}{ Model } & \multicolumn{1}{|c|}{$\begin{array}{c}\text { Sum of } \\
\text { Squares }\end{array}$} & \multicolumn{1}{|c|}{ df } & $\begin{array}{c}\text { Mean } \\
\text { Square }\end{array}$ & F & Sig. \\
\hline 1 & Regression & 152.342 & 5 & 30.468 & 195.30 & $.000^{\mathrm{b}}$ \\
& Residual & 33.007 & 211 & .156 & & \\
\cline { 2 - 6 } & Total & 185.349 & 216 & & & \\
\hline
\end{tabular}

a. Dependent Variable: Team Effectiveness

b. Predictors: (Constant), Fringe Benefits, Career Development Opportunities, Work Environment, Organizational Characteristics and Nature of work

Source: Authors Calculation Based on Survey Data 
Rathnasiri R.A. \& Mohottige S.

Wayamba Journal of Management 12 (2)

Table 06: Regression Results

\section{Coefficients}

\begin{tabular}{|c|c|c|c|c|c|c|}
\hline \multirow{2}{*}{\multicolumn{2}{|c|}{ Model }} & \multicolumn{2}{|c|}{$\begin{array}{l}\text { Unstandardized } \\
\text { Coefficients }\end{array}$} & \multirow{2}{*}{$\begin{array}{c}\text { Standardized } \\
\text { Coefficients }\end{array}$} & \multirow[t]{2}{*}{ t-stat } & \multirow[t]{2}{*}{ Sig. } \\
\hline & & B & Std. Error & & & \\
\hline 1 & (Constant) & .176 & .087 & & 2.023 & .000 \\
\hline & Fringe Benefits & .353 & .068 & .351 & 5.191 & .004 \\
\hline & Career Development & .145 & .079 & .143 & 1.835 & .005 \\
\hline & Work Environment & .168 & .088 & .167 & 1.909 & .003 \\
\hline & $\begin{array}{l}\text { Organizational } \\
\text { Characteristics }\end{array}$ & .093 & .067 & .092 & 1.367 & .005 \\
\hline & Nature of Work & .189 & .055 & .186 & 3.436 & .002 \\
\hline
\end{tabular}

a. Dependent Variable: Team Effectiveness

b. Predictors: (Constant), Fringe Benefits, Career Development Opportunities, Work Environment, Organizational Characteristics and Nature of Work

Source: Authors Calculation Based on Survey Data

Table 07: Ranking of Beta values of Independent Variables

\begin{tabular}{|l|c|c|}
\hline \multicolumn{1}{|c|}{ Independent Variables } & Beta coefficient & Rank \\
\hline Nature of Work & 0.189 & 2 \\
\hline Career Development Opportunities & 0.145 & 4 \\
\hline Working environment & 0.168 & 3 \\
\hline Organizational Characteristics & 0.093 & 5 \\
\hline Fringe Benefits & 0.353 & 1 \\
\hline
\end{tabular}

Source: Author Calculations 


\section{REFERENCES}

Aquino, K., Griffith, R. W., Allen, D. G., \&Hom, P. W. R. W., \&Sellaro, L, (2000), AMeta-Analysis of Antecedents and Correlates of Employee Turnover: Update, Moderator Tests, and Research Implications for the Next Millennium, Research Article.

Ashil and Rod, (2011). International Journal of Academic Research in Business and Social Sciences June 2013, Vol. 3(6) ISSN: 22226990109

Ayala Pines and Christina Maslach, (1981)

Combatting Staff BurnOut in a Day Care Center: A Case Study University of California at Berkeley.

Bettina F. Piko (2006), Satisfaction with Life, psychosocial Health and Materialism among Hungarian Youth, Hungary Journal of Health Psychology.

Burke, R. J. \& Greenglass, E. (1995). A longitudinal study of psychological burnout in teachers. Human Relations.
Central Bank Annual Reports (various issues), Central Bank of Sri Lanka

Cordes, C. L. and Dougherty, T.W. (1993). A review and integration of research on job burnout. Academy of Management Review.

Cordes, C.L., \& Dougherty, T.W. (1993). Job Satisfaction, Role Conflict and Autonomy of employees in the Greek Banking Organization. University of Thessaly, Karyes, 42100, Trikala, Greece.

De Dreu, C. K. W., \& West, M. A. (2001). Minority dissent and team innovation: The importance of participation in decision making. Journal of Applied Psychology Vol. 8.

E. Salas (2009). G .F Goodwin, and C.S Burke (Eds.), In team effectiveness in complex organizations: Cross-disciplinary perspectives and approaches,39-79.

French, j. R. and R. D. Caplan (1972) "Organizational stress and individual strain," Research Center for Group Dynamics 


$\begin{array}{ll}\text { Institute for Social } & \text { Correlates with Job } \\ \text { Research. The University } & \text { Satisfaction and Values, } \\ \text { of } & \text { Michigan }\end{array}$

Freudenberg, H.J., (1974), "Staff burnout". Journal of Social Issues.

Freundenberg, (1974). Postgraduate Medical Journal, The Liver Unit, Department of Medicine, King's College Hospital, Lonldon.

Gareth R. Jones and Jennifer M. George,(1998). The Experience and Evolution of Trust: Implications for Cooperation and Teamwork, The Academy of Management Review.

Halvorsen, K. (2013). Team decision making in the workplace: A systematic review of discourse analytic studies. Journal of Applied Linguistics and Professional Practice.

Harry j Martin, Job Satisfaction and Organizational Commitment in Relation to Work Performance and Turnover Intentions.

Kahn and Byosiere's, (1992), process of stress development in organizations.

Kahn et al. (1964) Role Conflict and Ambiguity:
Kevin Morrell, John Loan-Clarke and Adrian Wilkinson, (2001). Unweaving leaving: the use of models in the management of employee turnover, International Journal of Management Reviews.

Martin Loosemore and Tom Waters, Martin Loosemore, (2004), Journal of Management in Engineering, Published by American Society of Civil Engineers.

Maslach Burnout Inventory Manual (3rd Ed.). Palo Alto, CA: Consulting Psychologists Press. Maslach, C. \&Leiter, M. P. (1999). The Truth about Burnout. San Francisco: Jossey-Bass.

Maslach\& Jackson (1981). The Maslach Burnout Inventory, published by Consulting Psychologists Press.

Maslach, C. (1982). Burnout: The Cost of Caring. Englewood Cliffs, New Jersey: Prentice Hall.

Maslach, C., \&Marek, T. (Eds.), (1993) Burnout: A 
Multidimensional

Perspective - Research

Gate Published in

Schaufeli.

Maslach, C., Schaufeli, W. B., \&Leiter, M. P. (1993). Job burnout. Annual Review of Psychology.

Maslach, C., Schaufeli, W. B., \&Leiter, M. P. (2001). Job burnout. Annual Review of Psychology, 52, 397-422. Meier, S. T. (1984). The construct validity of burnout. Journal of Occupational Psychology, 57, 211-219.

Maslach, D., and Jackson, S. (1981). The measurement of experienced Burnout. Journal of Occupational Behavior, 2, 99-115.

Michelle A. Marks, John E. Mathieu and Stephen J. Zaccaro, (2001). A Temporally Based Framework and Taxonomy of Team Processes, The Academy of Management Review.

Mobley, W. H. (1982). Employee Turnover: Causes, Consequences and Control, Faculty of Business Administration University of Macau, E22Avenida da Universidad, Taipa, Macau, China,
Moore, J. E. (2000). Why is this happening? A causal attribution approach to work exhaustion consequences. Academy of Management Review, 25, 335-349.

Naquin, C. E., \& Tynan, R. O. (2003). The team halo effect: Why teams are not blamed for their failures. Journal of Applied Psychology, 88 (2): 332-340

P Boxall,K Macky, E Rasmussen, Labour turnover and retention in New Zealand: The causes and consequences of leaving and staying with employers, Asia Pacific Journal of HR, 2003.

Prendergast, Canice. 1999. "The Provision of Incentives in Firms." Journal of Economic Literature, 37 (1): 7-63.

Purani and Sahadev (2007), Level of Job Satisfaction and Intent to Leave Among Malaysian Nurses.

Purani and Sahadev 2007, Level of Job Satisfaction and Intent to Leave Among Malaysian Nurses, Business Intelligence, Vol. 3

Robert L. Mathis John H. Jackson, (2008), 
Rathnasiri R.A. \& Mohottige S.

Wayamba Journal of Management 12 (2)

\section{Changing Nature of Human Resource Management, Published by Southwestern College.}

Sekaran, U., (2013). Research Methods for Business. John Wiley \& Sons.

Stephen P. Robbins, Timothy A.Judge, Neharika Vohra, (2016).

Organizational Behavior, 15 ${ }^{\text {th }}$ Edition, Pearson Education, Inc., publishing as Prentice Hall.

Steve W.J. Kozlowski, Daniel R. Ilgen, (2006). Enhancing the Effectiveness of Work Groups and Teams Psychological Science in the Public Interest, vol. 7 (3): pp. 77-124. , First Published Dec 1, 2006. 